New Zealand Annual Review of Education (2017) 22: 5-20

DOI: https://doi.org/10.26686/nzaroe.v22ii0.4142

\title{
National Standards 2016: Retrospective Insights, Continuing Uncertainties and New Questions
}

\author{
Martin Thrupp \\ Faculty of Education, University of Waikato
}

New Zealand's National Standards policy has been deeply controversial in the education sector, especially amongst primary teachers and principals. This article provides a view of the National Standards from their introduction up until 2016, nearly a decade after they were first mooted. The issues covered: (i) offer retrospective insights, (ii) acknowledge continuing uncertainties, or (iii) ask questions that had become newly relevant by 2016. They include processes within the Ministry of Education, the role of advisory groups, the public release of National Standards data, and the origins and impact of the National Standards. They also include whether teachers and principals have been gradually won over to the National Standards, use of the National Standards in 'social investment', the Progress and Consistency Tool and possible wider political purposes of headline policies like the National Standards. A theme that connects the issues is concern about policy processes. The article concludes by calling for a more genuine commitment by Government to evidence-informed policy.

Keywords: national standards, New Zealand, primary assessment, policy origins, policy processes.

\section{Introduction}

New Zealand's National Standards system for assessing the achievement of primary school students involves teachers drawing on a range of quantitative and qualitative evidence to make 'Overall Teacher Judgements' about primary school achievement. The Overall Teacher Judgements are in reading, writing, and mathematics, on a four-point scale - 'well below', 'below', 'at' and 'above' and are reported to parents and, in an aggregated form, to the public. The idea was announced by the then Opposition Leader, John Key, in April 2007. Legislation, the Education (National Standards) Amendment Act 2008, was then put through under urgency by the newly elected National-led Government in December 2008. National Standards were officially launched in October 2009 and school-level, regional and national National Standards data were first released to the public in 2012 and have been released again each year since.

The National Standards policy has been deeply controversial in the education sector, especially amongst primary teachers and principals. There are numerous reasons for this including the international experience of high-stakes assessment, concerns that the particular features of this assessment system would have harmful effects on students and schools, the public release of achievement data for young students when there had been no recent New Zealand history of this, and concerns about consultation. A lot has been written about all of this over the years (e.g., Clark, 2010; Lee \& Lee, 2015; Poskitt, 2016; Thrupp, 2014).

This article provides a view of the National Standards since their introduction up to 2016, nearly a decade after they were first mooted. It presents a range of matters likely to be of interest to many educators, especially those who have been following the debates over 
National Standards over the years or who have been part of those debates. The issues covered here: (i) offer retrospective insights, (ii) acknowledge continuing uncertainties, or (iii) ask questions that had become newly relevant by 2016. Three of each of these kinds of issues are discussed here, and a theme that connects them is concern about policy processes. The article concludes by calling for a more genuine commitment by Government to evidence-informed policy. The article draws on the author's recent book The Search for Better Educational Standards: A Cautionary Tale (Thrupp, with Lingard, Maguire, \& Hursh, 2017). This book provides a detailed description and policy history of the National Standards. It also provides a discussion of the available research on the National Standards and puts this New Zealand 
development into an international context. Readers can refer to it for more background to the matters discussed here.

\section{Retrospective insight - The thinking within the Ministry of Education}

Although there are Ministry documents (2010a, 2010b) describing the process of creating the National Standards, these are formal accounts that reveal little about the Ministry's processes and decisions. But in 2015 a rare insider account was published by Vince Wright (2015) from the Australian Catholic University who was the lead writer of the Mathematics National Standards. He describes how the Ministry of Education struggled to respond to the rapid introduction of the National Standards:

Following the 2008 election, alarm bells went off in the Ministry of Education. In both policy and implementation, the bureaucracy was understandably still dressed in pink pyjamas. Accustomed to serving a Minister in a centre-left government, officials were suddenly required to implement a right-wing policy for which they were ill prepared. Some were philosophically opposed. The ink was barely dry on the revised New Zealand Curriculum ... a document with a 5-year consultative process behind it that encouraged diversity in approach by schools to meet the needs of their communities and students. Standards represented a U-turn in curriculum development and the selfdetermination of schools. (p. 592)

Wright reveals that the writing, assessment and reporting of the National Standards were allocated to separate teams within the Ministry but that this caused big problems:

In hindsight the separation of these work streams, in the interests of both division of labour and satisfying the competing factions within the Ministry, was the single biggest mistake in the implementation of national standards. There was failure to recognise the close relationships needed between the standards statements, measurement of those standards and reporting formats. (p. 592)

He goes on to comment:

As the writer I received no clear direction as to whether the standards should be set at minimal, average or elite levels of achievement. This policy vacuum opened the door for debate that should have occurred before the writing process began. That debate should have also considered adverse educational consequence of labelling young children as failures, given the stated goal of standards was to improve outcomes for all students. (p. 595)

What we can take from this is that while guidance was given to the developers of the National Standards, important issues about the nature and likely impact of the National Standards were set aside. Wright was sure Ministry officials understood issues such as the importance of the specific language used in the National Standards, but the officials had become "caught up in the politically driven imperative to implement the policy rapidly" (p. 596). Wright's account also describes Ministry officials playing down otherwise unpalatable developments. The phrase 'aspirational standards' became invented by Ministry officials when a scriptscrutiny comparison between the National Standards and a well-established formative test, 
the Progressive Achievement Test, suggested that fewer than $50 \%$ of average Year 8 students would achieve the National Standards in mathematics (p. 598). Moreover:

Another policy aim of the Ministry was to have all secondary students achieving at level two of the qualifications framework at senior secondary school ([National Certificate of Educational Achievement]; NCEA), and the argument was made that higher standards were needed at primary school for this to occur. Claims that the mathematics standards were written to provide an on-track progression to Level Two of NCEA are false. Projections of progress from the end of primary school to the requirements of senior secondary school were never considered when I wrote the numeracy standards. (Wright, 2015, p. 598)

Wright argues that the notion of aspirational standards and promulgation of the idea that the National Standards were linked to the National Certificate of Educational Achievement were 'damage control', following "ill-advised publication of the script-scrutiny exercise" (p. 600). He suggests that hasty justifications were needed because the "incoming government required a speed of implementation that was beyond the power of Ministry officials to deliver" (p. 599):

Important policy work had not been done so the issues of measurement and reporting were not thought through. This uncertainty combined with the demarcation of responsibilities for writing, assessment and reporting produced inconsistencies in message and provided willing critics like academics and union spokespeople with plentiful ammunition. (Wright, 2015, p. 599)

Also relevant here was the Ministry's enthusiasm for standards-based assessment while ignoring the way standards-based and norm-referenced assessments are linked in most assessment contexts. Unless pre-calibrated tests or pre-calibrated items/tasks are used, assessment against standards without some form of recourse to norms is very difficult. This is why, for instance, external assessment for the National Certificate of Educational Achievement came to incorporate the use of norms (called Profiles of Expected Performance) to monitor if unexpected shifts in the proportion of students gaining different National Certificate of Educational Achievement grades (Excellence, Merit, Achieved, Not achieved) were occurring.

\section{Retrospective insight - Whether formal consultation and advisory groups served any purpose}

Looking back prior to 2016, it is difficult to see any instances where the direction of National Standards policy shifted as a result of formal consultation or advisory group activity. To begin with, almost 5000 responses to a 2009 public consultation were analysed and reported by researchers at the New Zealand Council for Educational Research. They reported diffidence amongst parents with $38 \%$ of parents making negative comments about the National Standards system and only $14 \%$ making positive comments (Wylie, Hodgen, \& Darr, 2009). Yet this had little influence on the then Minister of Education, Anne Tolley, who was insistent 
on the merits and general popularity of National Standards. Her press release about the result of the consultation claimed that "consultation feedback shows strong support from parents for National Standards" (Tolley, 2009).

Later came a series of National Standards advisory groups. In February 2010 there was the establishment of a small National Standards Independent Advisory Group. In September 2010 the Minister added members and announced a National Standards Sector Advisory Group. The National Standards Sector Advisory Group seemed to stop meeting in early 2012. The National Standards, along with Public Achievement Information, became the focus of a subgroup of the Ministerial Cross-Sector Forum on Raising Achievement. With this CrossSector Forum then came the National Standards Aggregate Data Advisory Group, which was set up in 2013 after the National Standards data were released to the public. This group advises the Ministerial Cross-Sector Forum on Raising Achievement.

Each of these advisory groups had a different flavour but none of them amounted to much. The National Standards Sector Advisory Group aimed to "attract the confidence of the sector both in NSSAG and in the process of change being experienced in the education sector" (National Standards Sector Advisory Group, 2010). It made various recommendations to the Minister but never developed any substantial line of inquiry and by 2012 its meeting reports became full of assertions and fudging, for instance, "The Progress and Consistency Tool is the right strategy on which to rely" (National Standards Sector Advisory Group, 2012, p. 4). The National Standards Aggregate Data Advisory Group had more serious intent, advising the Government to find a more "compelling story" about the National Standards, to use a high profile "champion" to lead the thinking about the National Standards, to only report the National Standards every alternative year and to investigate the impact of the Standards on those students deemed 'below' (National Standards Aggregate Data Advisory Group, 2013). Recommendations from the National Standards Aggregate Data Advisory Group were not intended to be released publicly but only came to light following an Official Information Act request from the Green Party. None of its recommendations seem to have been taken up in any case. Each of these advisory groups was quietly discontinued or de-emphasised once their political usefulness had passed.

\section{Retrospective insight - Government releases of the National Standards data}

The National-led Government's release of the National Standards data in 2012 was controversial, and its plan to get the public interested in National Standards data never really took off. As it turned out, opposition to the release of the data had an impact as it became widely recognised that the National Standards were difficult to compare across schools. There was also the continuing problem of what to make of the data even if one took them at face value. The National-led Government gradually gave up trying to get much public traction with the data after all.

Data for 2013 were released in a more consistent format on the Government's Education Counts website than they had been initially. The 2013 data showed only small gains over 2012 but the Government certainly tried to make the most of the release. The then Minister of Education, Hekia Parata, described the overall results as a "pleasing advance on last year's data" and the data as "powerful" (Shuttleworth, 2013a). She also suggested such small gains meant that they were real: "The increase we see between last year and this year, it's been an incremental change of 1.2 percent, 1.4 percent. So seeing this consistency is very 
reassuring" (Educators dismiss claim of national standards improvement, 2013). But the New Zealand Principals' Federation, New Zealand Education Institute, the Greens and New Zealand First all poured cold water on the idea that the gains should be taken seriously, while the Opposition Education spokesperson, Chris Hipkins, used the opportunity to say that Labour would dump the National Standards (Educators dismiss claim of national standards improvement, 2013; Shuttleworth, 2013b). The New Zealand Council for Educational Research (2013) also weighed in with a warning against reading too much into the data, pointing out that since the National Standards had never been trialled, the first few years needed to be treated as a trial.

In March 2014 a Herald on Sunday editorial about parents choosing schools advised that "the different assessments used for National Standards make tables and data associated with them unsuitable as a best-school guide" (Parents - do homework on schools, 2014). The 2014 release (i.e., of 2013 aggregated data) was much more muted, possibly because it was election year. There were attempts to make something of the aggregated data including that "Pasifika students have made the most progress from 2011 to 2013" and that "achievement of Year 1 students in 2013 is lower across all subjects compared to 2012" (New Zealand Government, 2014). One response to regional differences drew attention to Northland's poverty (Standards reflect poverty - principals, 2014). The release of data for individual schools that year was in November 2014, later than ever. One comparison of National Standards and the National Certificate of Educational Achievement reminded readers that the introduction of the latter in secondary schools had also been fraught with difficulties but that National Standards had greater problems around 'consistency' because of lack of moderation (Moir \& Hartevelt, 2014).

In 2015 the aggregated and individual school National Standards data were again released with little fanfare. The approach taken this time was to start to release National Standards data along with other Public Achievement Information data on early childhood education participation and secondary school National Certificate of Educational Achievement results (Parata, 2015). There was a de-emphasising of the overall National Standards results and a highlighting of the National Standards regional successes. In any case, the 2015 releases attracted only passing media interest (for instance, J. Lewis, 2015). When Hekia Parata released the Public Achievement Information in August 2016, it showed National Standards achievement levels had barely moved from the previous year (Jones, 2016). Speaking in the House about the release of the public achievement information, Parata ignored the National Standards data and focussed instead on the National Certificate of Educational Achievement where the picture was more positive. Overall, it had become a far cry from the hopes and aspirations around publishing the data that the Government led off with in 2012.

\section{Continuing uncertainty - Where the National Standards came from}

Where the idea came from for New Zealand's idiosyncratic brand of National Standards is a matter that has never been publicly resolved. There are some obvious global influences as well as local policy history but there was no clear account of how they came together in the form announced on 2 April 2007 and subsequently developed into the National Standards.

In terms of global influences, National Standards can be viewed as a lagging and somewhat unusual response to the same climate of high-stakes national assessment that had long overtaken the school systems of other Anglo-American countries, for instance, England (Key Stage i.e., 'SATS' testing), the USA (No Child Left Behind, Race to the Top, the Common 
Core State Standards), and Australia (National Assessment Programme - Literacy and Numeracy). There is also the growth of international large-scale assessments such as the Programme for International Student Assessment run by the Organisation for Economic Cooperation and Development. Large-scale assessments and related data infrastructures may have more explanatory power in the case of the National Standards than is often realised. Although the New Zealand response to high-stakes national assessment was substantially delayed, New Zealand has never held back on other market and managerial reforms such as self-managing schools.

Locally, a move towards National Standards and the justification for them can be seen as early as April 2005. National's election manifesto of that year included the proposal to introduce National Standards in numeracy and literacy and establish a testing regime to determine if a child had achieved the standards by age seven (National education policies a blast from the past, 2005). At this time the idea of National Standards was still being accompanied by a national test and, according to some banter in the House, the sticking point was that the (then) Opposition Education spokesman, Bill English, wanted standards only but the (then) Leader of the Opposition, Don Brash, would not give up on a national test (Hansard, 2005).

In July 2005 Bill English launched a policy for schools at a meeting of the Auckland Primary Principals' Association. There was "the introduction of national literacy and numeracy standards where schools will be held accountable for ensuring their pupils reach them" but no longer any mention of a national test. Instead "National was now going to provide reading and maths vouchers to parents of children who do not meet national standards by the age of seven" (English, 2005). By August it seemed clearer that national testing was no longer in favour as "schools have a lot of data about students. They need to use that to enhance learning and not just leave it on the shelf" (Education policy Q\&A: Bill English, 2005).

In November 2006 Bill English introduced an Education (National Standards of Literacy and Numeracy) Amendment Bill to the Education Select Committee. The aim of the bill was to amend the 1989 Education Act to 'enable parents to be well-informed about students' schooling and to assess whether remedial action may be required for schools and students whose achievements fall short of the national standards" (p. 1). It would also allow:

the Minister [of Education], by notice in the Gazette, to publish agreed national standards in literacy and numeracy, and to require schools to provide information in their annual reports about the progress of students in respect of any national standards in literacy and numeracy that have been published. (p. 1)

This bill was unsuccessful but again seems to foreshadow John Key's announcement of National Standards as the "cornerstone" of National's intended education policy the following year.

Anne Tolley would later claim in the House that John Hattie invented the National Standards. Hattie himself denies this but does see himself as having had some influence on the policy. In a 2009 email exchange with the author understood to be 'for the record', Hattie says:

I did speak to Bill English and a coterie of National people a few years ago, and we talked about the value of standards and particularly formative assessment, knowing where "we" are and where "we" wish to be, the importance of progress, the realities of normal curves and thus progress and levels are critical (never one or the other), simple is rarely 
the answer. I later spoke, at his request, to John Key and his advisors ... and impressed him to avoid national testing or any version of it ... So was I the inventor - hardly as this notion has been around for eons. Was I the instigator - yes, I did push for clear criteria 
Thrupp, NZ Annual Review of Education (2017) 22: 5-20

for success of our system (of course, not that this is easy and simple!), and yes I did push

for clear implementation plans. (J. Hattie, personal communication, December 11, 2009)

\title{
Continuing uncertainty - The impact of the National Standards
}

In November 2013, the Research Analysis and Insight into National Standards project, a threeyear study of the enactment of the National Standards policy undertaken by the author and colleagues, released its final report. This concluded that:

\begin{abstract}
National Standards are having some favourable impacts in areas that include teacher understanding of curriculum levels, motivation of some teachers and children and some improved targeting of interventions. Nevertheless such gains are overshadowed by damage being done through the intensification of staff workloads, curriculum narrowing and the reinforcement of a two-tier curriculum, the positioning and labelling of children and unproductive new tensions amongst school staff. (Thrupp \& White, 2013)
\end{abstract}

Yet this is now some years ago and how the National Standards policy has subsequently impacted on students, families, and schools is largely unknown. There has been the School Sample Monitoring and Evaluation Project, an evaluation of the National Standards undertaken for the Ministry by NZ Maths Technology Ltd, initially over the period 2010-13 and then extended for two more years (Ward \& Thomas, 2016). This study produced some useful reports but was never able to be really searching about the National Standards because of the way it was framed to largely 'fine-tune' the Standards (see Thrupp \& Easter, 2012, section 2.4). There have also been New Zealand Council for Educational Research school surveys which have included questions on National Standards, with the most recent report discussed in the next section. And there have been quite a number of small studies (see discussion of these in Thrupp, with Lingard, Maguire, \& Hursh, 2017, Chapter 3). But overall, there has been remarkably little funded research on the National Standards for a policy that has become so central in New Zealand primary education.

Given all the funds spent elsewhere around the National Standards (e.g., promoting the policy, public release of data), it is hard not to conclude that the National-led Government has been reluctant to open the National Standards policy up to research-informed critique. This has resulted in a situation with numerous anecdotal claims but little recent research evidence. Even the Research Analysis and Insight into National Standards project itself was the result of funding from a teacher union, the New Zealand Educational Institute Te Riu Roa, since the National-led Government was not funding any broad investigations of the National Standards. The situation reflects a deterioration in educational research funding in New Zealand compared to the time when governments would still be prepared to fund research with the potential to be challenging. The Smithfield Project about the impact of educational markets in New Zealand (Lauder \& Hughes, 1999) is one important example.

\section{Continuing uncertainty - Whether teachers/principals are really being 'won over'}

As early as November 2011, former Education Minister Anne Tolley's biography on her Ministerial website was telling the reader that "[s]he has implemented the ... National 
Standards" (National Party, 2011). But the notion of implementing reforms tends to assume that politicians and policymakers decide on policies and those in schools simply do as they are told and put the intended policy into practice, regardless of circumstances. Clearly this is not what really happens and a more realistic understanding of what goes on in schools is the notion of policy enactment. This focuses on how policy is translated and reinterpreted by individuals and groups in schools amidst the messy complexities and uncertainties of schools operating in diverse settings and against the background of other education policies and wider social and political contexts (Ball, Maguire, \& Braun, 2012).

A recent New Zealand Council for Educational Research survey reports various findings that suggest principals and teaching staff in high socio-economic schools where National Standards achievement is highest are more favourably disposed towards National Standards than those in other schools (Bonne, 2016). Although the New Zealand Council for Educational Research advises that the relationship between decile and teacher and principal perspectives is not strong in their survey, students from advantaged backgrounds will be more likely to be judged 'at' or 'above' in the National Standards and so this system is likely to present fewer problems for high socio-economic schools. On the other hand, there is no external moderation, and because the Ministry of Education and Education Review Office do not have the resources to ensure school compliance with all the expectations of the policy, there is a great deal of 'wriggle room' for other schools as well. Taking an enactment perspective reminds us how they could manipulate National Standards data to be more successful. For instance, there is nothing to stop the staff at any school judging children 'at', when those at most schools would regard them as 'below'. So it might be that growing enthusiasm for the National Standards reflects increasing understanding of how to work the National Standards system. The recent New Zealand Council for Educational Research findings lend support to this idea. The proportion of principals supportive of National Standards in principle increased from $38 \%$ in 2013 to $44 \%$ in 2016 but the proportion who thought National Standards provided a valuable picture of student learning dropped from $37 \%$ to $23 \%$ over the same period (Bonne, 2016, p. 15).

It is also difficult to know how much to take any increase in support for National Standards at face value or whether it represents a shift in the subjectivity of principals. For instance, looking at the increase in the proportion of principals supportive of National Standards in principle, are these principals with much the same values who have just decided National Standards more OK than they used to be in 2013 or do the 2016 results reflect a more fundamental change in outlook amongst a new breed of principals? Or perhaps a bit of both? It's an interesting question given the development of a data-driven and data-responsive disposition amongst principals and teachers in Australia and the USA (Holloway-Libell, 2016; S. Lewis, 2016). It seems unlikely that this wouldn't happen in New Zealand also given that data have become so central to school-level policy and practice.

The Research Analysis and Insight into National Standards study undertaken during the introduction of the National Standards suggested that after an initial period of contestation, teachers and principals came to make a virtue out of necessity (Thrupp \& White, 2013). New demands related to the National Standards were to creep in because they were incremental. What wouldn't have been expected or acceptable a few years previously became 'business as usual'. There was too much risk for senior leaders of undermining their own leadership with staff by creating a kind of dissonance around the National Standards. They would effectively be saying 'We are doing this but I don't really agree with it'. It was easier to argue that the school could find a way through. The perspective then became that 
'if we are going to do the National Standards we are going to do them really well, in the same way we do our best at everything else.' Meanwhile, New Zealand primary principals appointed since 2010 have only ever known this role in a National Standards environment and as each year goes by will represent a greater proportion of the school leader workforce.

\section{New question - Whether National Standards will become linked into 'social investment'}

The National Standards system seems to be gradually being drawn into the Government's wider social investment approach to policy. A 2016 report by Deloitte and the New Zealand Institute for Economic Research explains:

The investment approach can be thought of as government activity undertaken on the basis of a return-on-investment justification. Using the investment approach, funding is made available on the basis of:

a). Data quantifying the issue or challenge

b). The likelihood of the proposed interventions to address the issue or challenge

c). Measurement and reporting back to decision-makers on the outcomes achieved by the interventions to enable calculation of the benefits. (p. 6)

National Standards started to become caught up in this when the National-led Government planned to use the National Standards data alongside a few other measures to track the progress of a group of schools and early-childhood centres in a given area (Moir \& Hartevelt, 2014). By 2016 the Government was drafting an update to the Education Act and consulting on changes to the planning and reporting framework that schools operate within. This included the suggestion that "annual reporting on National Standards would continue, with a move to student-level data" (Ministry of Education, 2016, p. 1). The emphasis on studentlevel data is important for furthering the social investment approach because it would allow the matching up of National Standards results with other kinds of government-held data about any particular student, for instance, particular social background indicators and financial allocations.

A 2016 report from the business think-tank, The New Zealand Initiative, discusses an Education System Modelling project being undertaken by the Ministry of Education since 2013 using data from Work and Income, the Department of Corrections, Child, Youth and Family, and the Ministry of Education itself (Udahemuka, 2016). This project identified a set of particular indicators for low achievement such as having a primary caregiver with less than the National Certificate of Educational Achievement Level 1 (i.e., low secondary school achievement) or having parents/caregivers who received a benefit. The New Zealand Initiative advocates that "if the risk factors that limit the chances of a student achieving a certain outcome are known, they should be considered when evaluating relative performance" (p. 44).

Although using performance in National Standards to allocate resources is a long-held Key Government aspiration, there is a new impatience about the social investment approach. It is very much about trying an intervention, measuring it, and discarding it quickly if it doesn't work in order to try something else. Unfortunately, the history of school improvement efforts illustrates that education interventions rarely make so much difference or so quickly, and there is a risk of useful interventions being discarded too quickly (Gray, 2001). The social 
investment approach also puts great weight on the significance of specific indicators and less on the overall context of deprivation or poverty. In this respect the social investment approach works to individualise and contain the cause of the underachievement, instead of supporting a more structural understanding of the problem in the round (Thrupp \& Lupton, 2006). From the social investment perspective a child or youth is held back not by the general 
effects of poverty and racism, but by specifics such as their mother's lack of education, their father in prison, an abusive family, and so on.

\section{New question - Whether Progress and Consistency Tool will become mandated}

The online Progress and Consistency Tool provides illustrations of student learning to inform a teacher's decisions about the achievement of any particular child on aspects of one of the National Standards learning areas: mathematics, reading or writing. The Progress and Consistency Tool then collects up the teacher's decisions across multiple aspects and uses psychometric calibration to recommend an Overall Teacher Judgement. It can be seen as an attempt to get closer to having the reliability provided by national testing while avoiding the prospect of national testing and its damaging consequences.

The Ministry of Education seems to have been pleased with the Progress and Consistency Tool, saying in an introductory module that "this is unique! Using teachers' judgements rather than relying solely on standardised testing of students is an international first" (The purpose of the Progress and Consistency Tool, n.d.) At the same time, the Progress and Consistency Tool has faced strong opposition because of its link to the National Standards. Debates about what the Progress and Consistency Tool would and would not do culminated in a united boycott of the trialling of the tool by primary teacher and principal organisations in June 2013. The following month, Hekia Parata was reported as saying that the Progress and Consistency Tool would not be compulsory on the grounds that it would "mandate itself" as schools would want to use it voluntarily (Shuttleworth, 2013c).

Over the years since the 2013 boycott, the Ministry has continued to promote what it was now describing as an "indispensable" tool (Ministry of Education, 2013) and the Progress and Consistency Tool has been gradually developed by several private companies and the New Zealand Council for Educational Research. Amongst the private companies involved was Maths Technology Ltd, meaning that the Ministry was contracting this company to both evaluate the National Standards and put in place the Progress and Consistency Tool framework intended to shore them up. Anecdotal evidence suggests trialling was more difficult than usual given the suspicion of the Progress and Consistency Tool within the sector. Nevertheless, trials did go ahead, workshops were held, and the Progress and Consistency Tool was launched in February 2015. A year later, fewer than 300 schools were using it, but by July 2016 the number of schools using the tool was up to 420 (Tuckey, 2016).

In the same month, the final report from Maths Technology Ltd reiterated that Overall Teacher Judgements, as done by teachers, were often not dependable and the mandating of the Progress and Consistency Tool seemed to get a little more likely (Ward \& Thomas, 2016). The social investment approach, as described above, would also seem to require improving the rigour of National Standards assessment through the Progress and Consistency Tool. The New Zealand Initiative supports collecting National Standards results for identified students and improving the rigour of National Standards assessment through the Progress and Consistency Tool:

Assessing the same would remain a challenge at primary and lower-secondary schools, not only because student level information is not centrally collected ... but as student proficiency is currently judged by individual teachers and assessment is not standardised between teachers or schools. [Referring mainly to PaCT[the Progress and Consistency 
Tool] ... there have been attempts to moderate teacher judgments at these levels, though uptake is minimal. (Udahemuka, 2016, p. 45)

Some of the claims for the Progress and Consistency Tool are sure to bear fruit as teachers use the tool, adjust their expectations and learn from the illustrations. But an increased risk of trading off interesting teaching and learning for time spent on assessment has to be one concern. This is because the time taken by the tool, estimated by one principal to be "up to an hour for each child, for each subject, at least twice a year" (quoted in Tuckey, 2016), is on top of gathering all the underlying evidence. While it might be argued that good teaching requires lots of assessment, teachers have a limited amount of time overall, and there will be opportunity costs if they are spending more time on assessment activities.

The main shortcoming of the Progress and Consistency Tool might be that it cannot recognise the underlying causes of variation between students and schools because there are no contextual inputs into the tool and so no sense of the value added by teachers and schools. Whereas the group boycotting the tool complained that it assumes that every child has the same background (New Zealand Principals' Federation, 2013), the developers would say the Progress and Consistency Tool works irrespective of background. Yet the tool still allows policymakers to make National Standards judgements about schools that ignore the impact of inequalities between them, for instance, the effects of diverse and unequal intakes and communities. The levels achieved by children in the National Standards may be better compared by using the Progress and Consistency Tool but without more context we are in no position to make sense of their higher or lower levels of achievement.

Although there are problems with 'value-added' assessment approaches such as taking adequate account of context, the Progress and Consistency Tool's developers have ended up reinforcing this inherently unfair National Standards assessment system based on raw data, i.e., that does not adjust for student backgrounds. While it may be argued that this Tool needs other analyses/approaches to deal with the inequalities represented by differential achievement, the developers of the Progress and Consistency Tool created it for a Government that has often been reluctant to acknowledge socio-economic issues in education.

\section{New question - Whether the National Standards have had wider political purposes}

By the third term of the National-led Government, the National Standards became less debated but the shape of wider economic and social changes has become clearer and a broader vantage point more compelling. These changes have included privatisation, a decline in public spending, and more obvious signs of social inequality.

Despite some high profile failures, by 2016 privatisation reforms had occurred many times across the New Zealand public sector under the National-led Government and were continuing to occur, including, for instance, selling off state housing, and contracting out the running of some prisons. The social investment approach, as discussed above, is being rolled out not only into education but also social services, supported by Treasury and drawing on Statistics New Zealand's Integrated Data Infrastructure. At the same time, Government is being reduced and the public sector is having to do more with less. Analysis of the 2016 budget shows that spending on public services is shrinking with "tangible reductions in spending on health, education and family support" (Child Poverty Action Group, 2016, p. 8). 
Any new spending mostly offsets the effects of forecast inflation and expected population growth. It is only spending on superannuation that is forecast to rise sharply as the post-war 
baby-boomers reach retirement age and the Government holds to its political positioning of maintaining superannuation entitlements around the current level.

Rapidly rising house prices have also led to huge increases in personal wealth for many of the older generation, but younger and poorer New Zealanders struggle to get into accommodation and to afford much less once accommodation has been paid for. Many people just scrape by while others buy up rental properties and new cars and overseas holidays. New migrants are both welcomed and blamed for this state of affairs.

Recognition of this wider background places the National Standards in a different light when viewing them just as an educational reform. It makes the political campaigns around introducing and then publicly releasing the National Standards seem like something that preoccupied educators and appeased parents and the public while more fundamental changes to New Zealand education and society were afoot. This argument connects with what Bryan Gould has written about the legacy of Prime Minister John Key who resigned in December 2016: "[His] personality was merely the means by which a deadly serious re-making of New Zealand - along ideological lines - was being undertaken" (Gould, 2016). It seems likely that as well as personalities, signature or headline policies like the National Standards may have also acted as a political smokescreen, distracting from a wider malaise.

\section{Conclusion}

The retrospective insights discussed here may be of little surprise to readers but have only become clear over time. There are other issues that remain unresolved and the future for the National Standards is uncertain also. At the time of writing, National Standards remain one of the issues that most clearly divides the political parties. Of the four largest, National remains committed to the National Standards but Labour, the Greens and New Zealand First are all firmly opposed.

Looking back from 2016 perhaps the most concerning thing about the National Standards experience is how little genuine commitment there was on the part of the Nationalled Government to assess the pros and cons of the Standards and respond accordingly. The 'Cautionary Tale' book discusses numerous other instances where evidence that casts doubt on the National Standards was ignored or dismissed by Ministers of Education and senior policymakers of the National-led Government or where evidence has not been sought in the first place.

This does not bode well for educational research in New Zealand. Researchers need to have a sense that if their research is carried out and reported reasonably well, it will be taken seriously; also that they can still get government funding for research even if their interests and findings are not on message. In recent times around high-profile policies like the National Standards, this has simply not been the case. As the Hon Bill English said in the House on 19 November 2009, "This Government has the capacity to make its own distinctions between good advice and bad advice. Advice we disagree with is bad advice; advice we agree with is good advice" (Hansard, 2009). Although this was undoubtedly a tongue-in-cheek comment, in many ways it has turned out to be a true word spoken in jest. Australian academic Bob Lingard has written in response to the 'Cautionary Tale' book: 
The analysis of Kiwi Standards ... seems to demonstrate that instead of evidenceinformed policy what we have here is more a case of policy-based evidence, with the political in the Kiwi Standards very much overriding research evidence ... to the detriment of the reform. (Lingard, 2017)

\section{References}

Ball, S. J., Maguire, M., \& Braun, A. (2012). How schools do policy: Policy enactment in the secondary school. London: Routledge.

Bonne, L. (2016). National Standards in their seventh year: Findings from the NZCER national survey of primary and intermediate schools. Wellington: NZCER.

Child Poverty Action Group. (2016, May). A band aid budget: CPAG's analysis of the 2016 government budget. Retrieved from http://www.cpag.org.nz/assets/Budget/ CPAG\%202016\%20May\%20Budget\%20Review\%20Final.pdf.

Clark, J. (2010). National Standards: The public debate - What was it all about? New Zealand Journal of Teachers' Work, 7(2) 106-124.

Deloitte \& New Zealand Institute of Educational Research. (2016). State of the State New Zealand 2016 social investment: Summary report. Retrieved from https://www2.deloitte.com/nz/en/pages/public-sector/articles/the-state-of-thestate.html

Education policy Q\&A: Bill English. (2005, August 25). New Zealand Herald. Retrieved from http://www.nzherald.co.nz/nz/news/article.cfm?c_id=1\&objectid=10342382

Educators dismiss claim of national standards improvement. (2013, June 11). Radio New Zealand. Retrieved from http://www.radionz.co.nz/news/national/137312/educatorsdismiss-claim-of-national-standards-improvement.

English, W. (2005, July 1). Bill English: Launch of National's Schools Policy (National Party speech). Scoop. Retrieved from http://www.scoop.co.nz/stories/PA0507/S00016.htm

Gould, B. (2016, December 14). Labour Party never really knew what they were dealing with in John Key. New Zealand Herald. Retrieved from http://www.nzherald.co.nz/politics/news/article.cfm?c_id=280\&objectid=11765941

Gray, J. (2001). Introduction: Building for improvement and sustaining change in schools serving disadvantaged communities. In M. Maden (Ed.), Success against the odds: Five years on. London: Routledge Falmer.

Hansard. (2005, April 14). Questions \& answers, 12: Primary Students: Compulsory National Testing. 625, 20055.

Hansard. (2009, November 19). Questions for oral answer, Questions to Ministers 4. Hon David Cunliffe (Labour New Lynn) to the Minister of Finance. 659, 7831.

Holloway-Libell, J. (2016, November). Teachers as perpetual learners: A teacher evaluation system in the USA. Paper presented at Australian Association for Research in Education, Melbourne.

Jones, N. (2016, August 9). Primary school student achievement stalls, high school gender gap persists. New Zealand Herald. Retrieved from http://www.nzherald.co.nz/nicholasjones/news/article.cfm?a_id=715\&objectid=11690237

Lauder, H., \& Hughes, D., with Watson S., Waslander, S., Thrupp, M., Strathdee, R., Simiyu, I., Dupuis, A., McGlinn, J., \& Hamlin, J. (1999). Trading in futures: Why markets in education don't work. Buckingham: Open University Press. 
Lee, G., \& Lee, H. (2015). New Zealand: The politics of national standards in primary schools. In M. Crossley, G. Hancock, \& T. Sprague (Eds.), Education in Australia, New Zealand and the Pacific (pp. 112-141). London: Bloomsbury Academic.

Lewis, J. (2015, August 28). Otago pupils top performers. Otago Daily Times. Retrieved from http://www.odt.co.nz/news/dunedin/350143/otago-pupils-top-performers.

Lewis, S. (2016, November). Datafying the teaching 'profession': Reconstituting the teaching subject through high-stakes testing and value-added measures (VAM). Paper presented at Australian Association for Research in Education, Melbourne.

Lingard, B. (2017). An Australian, global and policy perspective. In M. Thrupp with B. Lingard, M. Maguire, \& D. Hursh (Eds.), The search for better educational standards: A Cautionary Tale. Dordrecht: Springer.

Ministry of Education. (2010a). Designing the reading and writing standards for years 1-8. Retrieved from https://nzcurriculum.tki.org.nz/content/download/4942/71062/file/ Designing\%20the\%20Reading\%20and\%20Writing\%20Standards090610.pdf.

Ministry of Education. (2010b). Designing the mathematics standards for years 1-8. Retrieved from https://nzcurriculum.tki.org.nz/.../Designing\%20the\%20Mathematics\%20Standards.pdf

Ministry of Education (2013, August 12). A deeper understanding. Education Gazette Retrieved from http://www.edgazette.govt.nz/Articles/Article.aspx?Articleld=8830

Ministry of Education. (2016). Update of The Act: Planning and reporting framework. Wellington: Author. Retrieved 4 April 2016 from http://www.education.govt.nz/ ministry-of-education/consultations-and-reviews/updating-the-education-act-1989

Moir J., \& Hartevelt. J. (2014, November 13). National Standards: Learning from NCEA mistakes. Stuff http://www.stuff.co.nz/national/education/10739005/NationalStandards-learning-from-NCEA-mistakes.

National education policies a blast from the past. (2005). NZEI Rourou, 17(4), 5.

National Party. (2011). Hon. Anne Tolley: Biography. Retrieved from http://www.national.org.nz/Bio.aspx?Id=272

National Standards Aggregate Data Advisory Group. (2013). Recommendations (Unpublished paper, retrieved 15 October 2013). Wellington: Author.

National Standards Sector Advisory Group. (2010). NSSAG work programme. Retrieved 16 December 2011 from http://nssag.minedu.govt.nz/programme-of-work

National Standards Sector Advisory Group. (2012). NSSAG Meeting \#9 23 February 2012 Chair's Report. Retrieved 6 June 2012 from http://nssag.minedu.govt.nz/meeting-9february-2012/

New Zealand Government. [Poster] (2014). National Standards Results 2013.

New Zealand Council for Educational Research. (2013, June 11). NZCER comments on National Standards aggregated data [Press release]. Retrieved from http://www.scoop.co.nz/stories/ED1306/S00060/nzcer-comments-on-nationalstandards-aggregated-data.htm

New Zealand Principals' Federation. (2013, June 17). 'PaCT' sent packing by teaching profession [Joint media release]. Retrieved from http://nzpfacnz2.digiwebhosting.com/?q=list/Releases/2013/\%E2\%80\%98PaCT\%E2\%8 0\%99_sent_packing_by_teaching_profession-17_June_2013

Parata, H. (2015, July 23). Exciting progress in educational achievement [Media Release]. Retrieved from https://national.org.nz/news/2015-07-23-exciting-progress-ineducational-achievement 
Parents - do homework on schools. [Editorial] (2014 March 2). Herald on Sunday. Retrieved from http://www.nzherald.co.nz/opinion/news/article.cfm?c_id=466\&objectid=11212255

Poskitt, J. M. (2016). Communication and collaboration: The heart of coherent policy and practice in New Zealand Assessment. In L. Allal \& D. Laveault (Eds.), Assessment for learning: Meeting the challenge of implementation (pp. 93-110). Heidelberg: Springer.

Shuttleworth, K. (2013a, June 11). Parata: Concerning trends in National Standards data. New Zealand Herald. Retrieved from http://www.nzherald.co.nz/nz/ news/article.cfm?c_id=1\&objectid $=10889744$

Shuttleworth, K. (2013b, June 11). Labour would dump National Standards. New Zealand Herald. Retrieved from http://www.nzherald.co.nz/nz/news/article.cfm?c_ $\mathrm{id}=1$ \&objectid $=1088984$

Shuttleworth, K. (2013c, July 17). Education Ministry backs down on computer toolFederation. New Zealand Herald. Retrieved from http://www.nzherald.co.nz/ $\mathrm{nz} /$ news/article.cfm?c_id=1\&objectid=10899905

Standards reflect poverty. (2014, July 25). Radio New Zealand. Retrieved 6 November 2016 from http://www.radionz.co.nz/news/national/250591/standards-reflect-povertyprincipals

The Purpose of the PaCT (n.d.). Part of the interactive module: 'The PaCT frameworks explained'. Retrieved from https://pactinfo.education.govt.nz/about-the-pact

Thrupp, M. (2014). At the eye of the storm: Researching schools and their communities enacting National Standards. New Zealand Journal of Educational Studies, 49(1), 6-20.

Thrupp, M., with Lingard, B. Maguire, M, \& Hursh, D. (2017). The search for better educational standards: A cautionary tale. Dordrecht: Springer.

Thrupp, M., \& Easter. A. (2012). Research, analysis and insight into National Standards (RAINS) project: First report: Researching schools' enactments of New Zealand's National Standards Policy. Wellington: NZEI.

Thrupp, M., \& Lupton, R. (2006). Taking school contexts more seriously: The social justice challenge. British Journal of Educational Studies, 54(3), 308-328.

Thrupp, M., \& White, M. (2013). Research, analysis and insight into National Standards (RAINS) Project. Final report: National Standards and the damage done. Wellington: NZEI.

Tolley, A. (2009, September 20). Parents support national standards. [Media Release]. Retrieved from https://www.beehive.govt.nz/release/parents-support-nationalstandards

Tuckey, K. (2016, July 21). National standards assessments 'lack dependability.' Retrieved from http://www.stuff.co.nz/national/education/82350450/National-standardsassessments-lack-dependability

Udahemuka, M. (2016). Signal loss: What we know about school performance. Wellington: New Zealand Initiative.

Ward, J., \& Thomas. G. (2016). National standards: School sample monitoring \& evaluation project, 2010-2014: Report to the Ministry of Education. Dunedin, NZ: New Zealand Maths Technology. Retrieved from https://www.educationcounts.govt.nz/ publications/series/National_Standards/National-Standards-2010-2014.

Wright, V. (2015). Globalisation and the New Zealand numeracy standards: In pursuit of excellence. In J. Zaida (Ed.), Second international handbook on globalisation, education 
and policy research (pp. 589-603). Dordrecht, Netherlands: Springer. doi.10.1007/97894-017-9493-0.

Wylie, C., Hodgen, E., \& Darr, C. (2009, August). National standards consultation analysis. Report for the Ministry of Education. Wellington: NZCER. Retrieved from www.minedu.govt.nz/theMinistry/Consultation/NationalStandards/SummaryOfRespo nses/EducationSector.aspx

Martin Thrupp is Head of Te Whiringa School of Educational Leadership and Policy at the University of Waikato. His research interests are in education policy with a particular focus on the lived effects of policy across socially diverse and unequal communities. His most recent work involves a comparative study of privatisation of education in New Zealand, Sweden and Finland.

Email: thrupp@waikato.ac.nz 